Eur J Clin Chem Clin Biochem

1995; 33:705-710

(c) 1995 Walter de Gruyter \& Co.

Berlin - New York

\title{
Effect of Tamm-Horsfall Protein on Calcium Oxalate Precipitation
}

\author{
By Jasminka Benković ${ }^{1}$, Helga Furedi-Milhofer ${ }^{2}$, Vladimir Hlady ${ }^{2}$, Dubravka Čvorišćec ${ }^{1}$ and \\ Ana Stavljenić-Rukavina ${ }^{1}$
}

${ }^{1}$ Klinički zavod za laboratorijsku dijagnostiku, Klinički bolnički centar Zagreb, Zagreb, Hrvatska Clinical Institute of Laboratory Diagnosis, Zagreb University Clinical Hospital, Zagreb, Croatia

2 Institut Ruder Bošković, Zagreb, Hrvatska

Ruđer Bošković Institute, Zagreb, Croatia

(Received May 11, 1994//January 20/August 3, 1995)

Summary: The effect of Tamm-Horsfall protein isolated from urine of healthy subjects on calcium oxalate precipitation was studied in model systems of precipitation. The study was performed using following conditions: concentrations of calcium chloride $10 \mathrm{mmol} / \mathrm{l}$, sodium chloride $150 \mathrm{mmol} / \mathrm{l}$, oxalic acid $300 \mu \mathrm{mol} / \mathrm{l} ; \mathrm{pH} 6.0$, and temperature $310 \mathrm{~K}$. The concentration of Tamm-Horsfall protein varied between $1-10 \mathrm{mg} / \mathrm{l}$. The kinetics of calcium oxalate precipitation was observed by measuring the number and volume of particles in the suspension, and the precipitate composition by an optic microscope. In all the studied systems, the precipitate morphology corresponded to pure calcium oxalate monohydrate. Tamm-Horsfall protein was found to inhibit the growth of calcium oxalate monohydrate crystals and stimulate their aggregation in the given experimental conditions. Both effects were enhanced by increase in the concentrations of Tamm-Horsfall protein and were most pronounced at the concentration of TammHorsfall protein of $10 \mathrm{mg} / \mathrm{l}$.

\section{Introduction}

Tamm-Horsfall protein is a membrane glycoprotein originating from the kidney. It is formed in the epithelial cells of the ascending limb of Henle's loop (1-4) and in the proximal part of the distal tubule as a molecule with a relative molecular mass of 80000 . In urine of healthy subjects, $90 \%$ of Tamm-Horsfall protein is found in the form of aggregates with a relative molecular mass of $7 \times 10^{6}(5)$ and to a minor extent $(10 \%)$ in the form of subunits $(80000)$ and polymers $\left(28 \times 10^{6}\right)(6)$. The role of Tamm-Horsfall protein in the formation of urinary calculi has been known for quite some time, but literature data on its action still vary considerably. According to some authors, Tamm-Horsfall protein is an inhibitor of calcium crystal growth and aggregation $(7-9,12,17,18)$, whereas others believe that it is actually a promotor of the above events $(10,11,19)$. The action of Tamm-Horsfall protein as an inhibitor or a promotor of calcium oxalate crystal growth and aggregation appears to depend on the degree of its aggrega- tion (10), ionic strength of the medium and the glycoprotein concentration. At low ionic strength, urine Tamm-Horsfall protein acts as an inhibitor of calcium oxalate crystallization (12). This inhibitory action is also pronounced at very low concentrations of TammHorsfall protein (11). Tamm-Horsfall protein polymerization in highly concentrated urine results in an opposite action, i.e. in stimulation of calcium oxalate crystal aggregation $(10,11)$. Such an effect of TammHorsfall protein is probably due to a decrease in urine $\mathrm{pH}$ and increase in urine ionic strength (10). Therefore, the aim of this study was to assess calcium oxalate as the most common constituent of urinary calculi, and to determine whether Tamm-Horsfall protein acts as an inhibitor or as a promotor of calcium oxalate precipitation, and how Tamm-Horsfall protein influences the processes of growth and aggregation of calcium oxalate crystals. 


\section{Materials and Methods}

Tamm-Horsfall protein was isolated from urine of healthy adults, males and females, by multiple precipitation with $0.58 \mathrm{~mol} / \mathrm{l} \mathrm{NaCl}$ $(13,14)$.

Pooled urine was diluted with equal amount of distilled water. Solution $\mathrm{pH}$ was adjusted to 5.0 using $\mathrm{HCl}$ solution of $1 \mathrm{~mol} / \mathrm{l}$. Solid $\mathrm{NaCl}$ was added to give a final concentration of $0.58 \mathrm{~mol} / \mathrm{h}$. The urine was left at $4^{\circ} \mathrm{C}$ for $48 \mathrm{~h}$. The precipitate was collected by centrifugation at $3000 \mathrm{~min}^{-1}$ for $20 \mathrm{~min}$ at $4{ }^{\circ} \mathrm{C}$ and washed with ice-cold $\mathrm{NaCl}$ solution of $0.58 \mathrm{~mol} / \mathrm{l}$. The precipitate was dissolved in 21 water. $\mathrm{NaCl}$ was then added to a final concentration of 0.58 $\mathrm{mol} / \mathrm{l}$ and the sample left overnight at $4^{\circ} \mathrm{C}$. The suspension was centrifuged at $3000 \mathrm{~min}^{-1}$ for $20 \mathrm{~min}$ at $4^{\circ} \mathrm{C}$. The precipitate was washed with ice-cold $\mathrm{NaCl}$ solution of $0.58 \mathrm{~mol} / \mathrm{l}$, and redissolved in water. Following a further addition of $\mathrm{NaCl}$, as described above, the material was dissolved in the minimum amount of water and dialysed against distilled water at $4{ }^{\circ} \mathrm{C}$ until free of chloride.

The purity of isolated Tamm-Horsfall protein was tested by immunoelectrophoresis with specific antiserum to Tamm-Horsfall protein (IgG fraction, Institute of Immunology, Zagreb, Croatia) and complete antihuman serum (Behring, Marburg, Germany). Complete antihuman serum was used to determine whether isolated TammHorsfall protein is free of albumin and other serum proteins which may be present in urine.

Protein concentration was determined by the method of Rieder (15) and was found to be $2.5 \mathrm{~g} / \mathrm{l}$. The concentration was tested by measuring the light absorption on a Hilger-H-700 instrument at a wavelength of $277 \mathrm{~nm}$. Protein concentration was calculated from $\mathrm{E}=\varepsilon \times \mathrm{c} \times$ d. $\varepsilon_{1 \mathrm{~cm}}^{1 \%}=10.8$ at $277 \mathrm{~nm}$ (16). Solutions of TammHorsfall protein concentrations of $1,2.5,5,7.5$ and $10 \mathrm{mg} / 1$ were prepared by Tamm-Horsfall protein dilution with tridistilled water. The solutions of $\mathrm{NaCl}$ of $150 \mathrm{mmol} / \mathrm{l}, \mathrm{CaCl}_{2}$ of $20 \mathrm{mmol} / \mathrm{l}$ and oxalic acid of $600 \mu \mathrm{mol} / \mathrm{l}$ were prepared from p.a. chemicals (Kemika, Zagreb) and filtered through a $0.22 \mu \mathrm{m}$ Millipore filter. Oxalic acid $\mathrm{pH}$ was adjusted to 6.0 using $\mathrm{NaOH}$ solutions of $1 \mathrm{~mol} / \mathrm{l}$ and $0.1 \mathrm{~mol} / \mathrm{l}$. All solutions were thermostasized at $310 \mathrm{~K}$. Precipitating systems were prepared by mixing equal volumes (100 $\mathrm{ml}$ ) of $\mathrm{NaCl}-\mathrm{CaCl}_{2}$ and $\mathrm{NaCl}$-oxalic acid solutions, so that final concentrations in the system were: $150 \mathrm{mmol} / \mathrm{l} \mathrm{NaCl}, 10 \mathrm{mmol} / \mathrm{l}$ $\mathrm{CaCl}_{2}$ and $300 \mu \mathrm{mol} / \mathrm{l}$ oxalic acid. Subsequently, an appropriate amount of Tamm-Horsfall protein was added. Before the measurement, the precipitating systems were mixed for $1 \mathrm{~min}$ at $340 \mathrm{~min}^{-1}$.

The kinetics of calcium oxalate precipitation was observed by the analysis of changes in the values of total particle number $\left(N_{\text {tot }}\right)$ and total precipitate volume $\left(\mathrm{V}_{\text {tot }}\right)$ during $2 \mathrm{~h}$, every $5 \mathrm{~min}$, on a Coulter Counter MO TA. Changes in the precipitate composition were observed by an Orthoplan optical microscope (E. Leitz, Wetzlar). $\mathrm{N}_{\text {tot }}$ is one of the output data of the Coulter particle counter, and the values of $V_{t o t}$ were calculated from the output data for each measuring time $\left(v_{n}\left(d_{n}\right), V_{n p}, N_{t o t}\right)$, according to the following formulas:

$$
\begin{array}{ll}
v_{n} & =\left(d_{n}^{3} / 6\right) \\
f_{n} & =V_{n p} / v_{n} \\
N_{n} & =\left(f_{n} / \Sigma f_{n}\right) N_{\text {tot }} \\
V_{n} & =N_{n} v_{n} \\
V_{\text {tot }} & =\sum V_{n}=\sum N_{n} v_{n},
\end{array}
$$

where

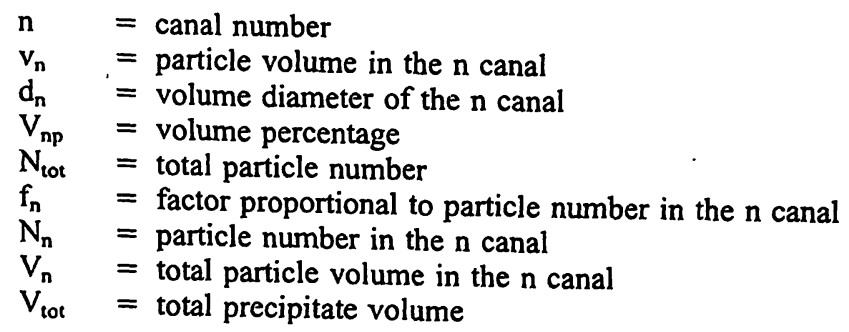

The above mentioned formulas were used to calculate volume fractions $V_{\text {single }}$ (total particle volume with volume diameter of 1.62 $\mu \mathrm{m} \leq \mathrm{d} \leq 8.2 \mu \mathrm{m}$ ) and $\mathrm{V}_{\text {aggr }}$ (total particle volume with volume diameter of $8.2 \mu \mathrm{m}<\mathrm{d} \leq 52.0 \mu \mathrm{m}$ ), as follows:

$V_{\text {single }}=\Sigma V_{n}=\Sigma N_{n} V_{n}$

$V_{\text {aggr }}=\Sigma V_{n}=\Sigma N_{n} V_{n}$

The $V_{\text {single }}$ volume fraction corresponded to particles of small volume diameter, i. e. to individual crystals of calcium oxalate. The $\mathrm{V}_{\text {aggr }}$ volume fraction included particles of large volume diameter that correspond to aggregates of calcium oxalate crystals.

In addition, the crystal growth parameter, a, was defined as the increase in the total volume of small particles $\left(V_{\text {single }}\right)$ with time, using the following formula:

$$
a=\frac{V_{\text {single }}(t)-V_{\text {single }}(1 \mathrm{~min})}{t},
$$

where

$\mathrm{V}_{\text {single }}(\mathrm{t}) \quad=$ total small particle volume at time $\mathrm{t}$

$\mathrm{V}_{\text {single }}(1 \mathrm{~min})=$ total small particle volume at the beginning of measurement (after $1 \mathrm{~min}$ )

$\mathrm{t}=\mathrm{h}$ time at which the slope of the $\mathrm{V}_{\text {single }}$-time curve reached its maximum

The crystal aggregation parameter, $b$, was defined as the change in the proportion of aggregated particles $\left(\mathrm{V}_{\text {aggr }}\right)$ relative to total precipitate volume $\left(\mathrm{V}_{\text {tot }}\right)$ from the beginning of measurement $(\min 1)$ to $\min 50$ of precipitation:

$$
\mathrm{b}=\frac{\mathrm{V}_{\mathrm{aggr}(50 \mathrm{~min})}-\mathrm{V}_{\mathrm{aggr}(1 \mathrm{~min})}}{\mathrm{V}_{\text {tot(50 min })}-\mathrm{V}_{\text {tot(1 min })}},
$$

where

$$
\begin{aligned}
\mathrm{V}_{\text {aggr }(1 \mathrm{~min})}= & \text { volume of aggregated particles after } 1 \mathrm{~min} \\
\mathrm{~V}_{\text {aggr(50 min })=} & \text { volume of aggregated particles after } 50 \mathrm{~min} \text { of pre- } \\
& \text { cipitation } \\
\mathrm{V}_{\text {tot }(1 \mathrm{~min})}= & \text { total precipitate volume after } 1 \mathrm{~min} \\
\mathrm{~V}_{\text {tot }(50 \mathrm{~min})}= & \text { total precipitate volume after } 50 \mathrm{~min} \text { of precipita- } \\
& \text { tion }
\end{aligned}
$$

\section{Results}

\section{Testing of purity of isolated Tamm-Horsfall protein}

Immunoelectrophoresis with specific antiserum to Tamm-Horsfall protein showed a single precipitate, thereby we concluded that isolated protein was TammHorsfall protein. Immunoelectrophoresis with complete antihuman serum showed no precipitate, i.e. isolated Tamm-Horsfall protein was free of albumin and other serum proteins.

\section{Precipitation of calcium oxalate in a Tamm- Horsfall protein-free system}

Changes in the particle distribution according to their number and volume are presented in figure 1 , showing that particles with volume diameter of $\leq 8.2 \mu \mathrm{m}$, i. e. individual calcium oxalate crystals, predominated by min 50 of precipitation, while the proportion of aggregated particles with volume diameters of $>8.2 \mu \mathrm{m}$ was 
negligible. Only later during precipitation did a shift in the volume distribution toward large particles occur, indicating aggregation of calcium oxalate crystals. The curve delineating the change in the distribution of particles according to their number (fig. 1) shows the proportion of particles with large volume diameter increased with time, also pointing to particle aggregation. The presence of pure calcium oxalate monohydrate in the precipitate was demonstrated by optical microscopy.

The total number of particles $\mathrm{N}_{\text {tot }}$ increased abruptly during the first five minutes of precipitation (systems with oxalate concentrations of $300 \mu \mathrm{mol} / 1$ and $200 \mu \mathrm{mol} / \mathrm{l}$ ), which was accompanied by a gradual increase in $V_{\text {tot }}$ (fig. 2), whereafter $\mathrm{N}_{\text {tot }}$ decreased and $\mathrm{V}_{\text {tot }}$ continued to slowly rise for some time, which corresponded to the phase of crystal growth. About min 30 of precipitation, $\mathrm{V}_{\text {tot }}$ assumed constant values, whereas $\mathrm{N}_{\text {tot }}$ continued to decrease due to aggregation of calcium oxalate monohy-

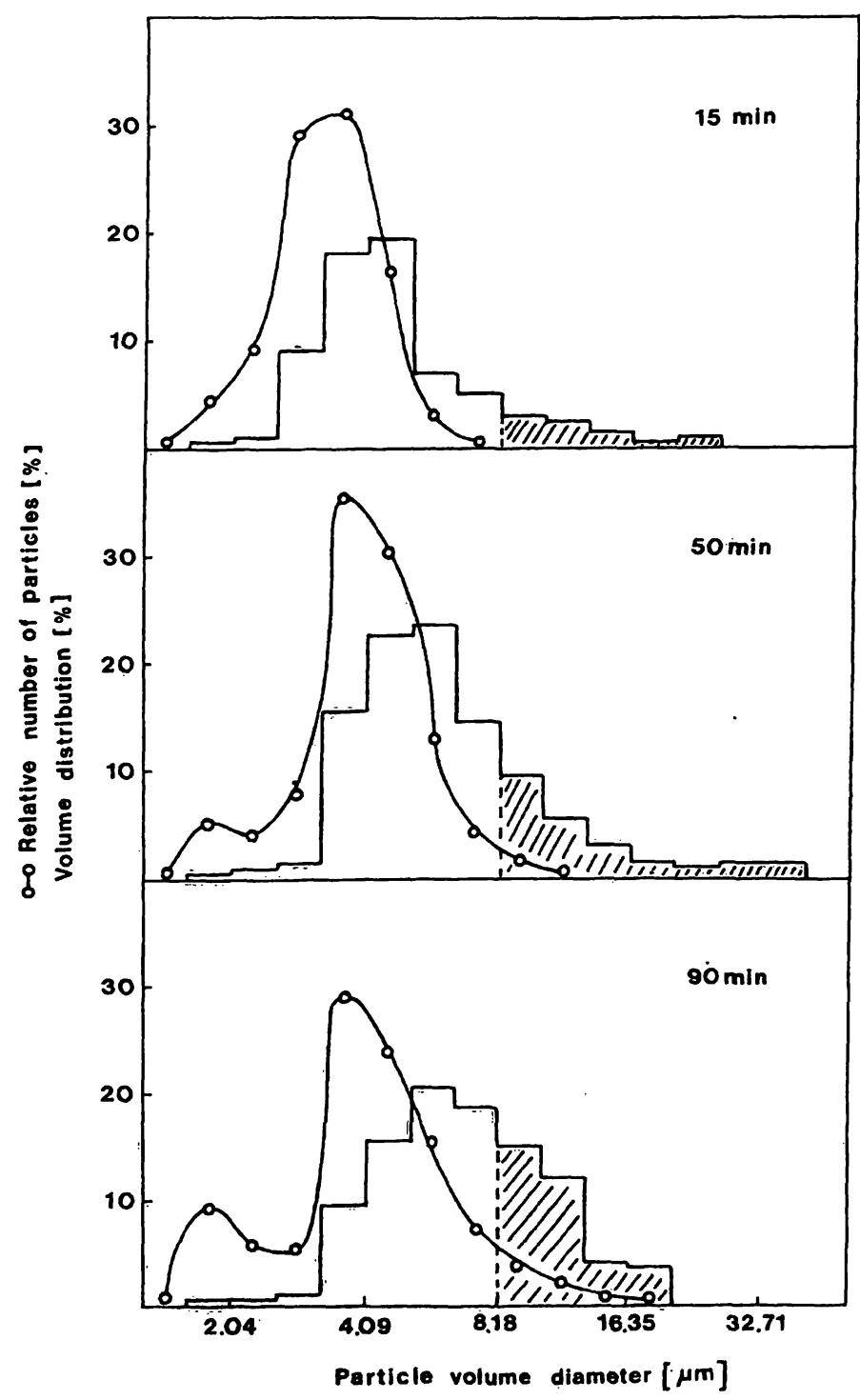

Fig. 1 Change in distribution according to number (-O-) and volume (histogram) of particles in a Tamm-Horsfall protein-free system $\left(\mathrm{c}(\mathrm{NaCl})=150 \mathrm{mmol} / \mathrm{l}, \mathrm{c}\left(\mathrm{CaCl}_{2}\right)=10 \mathrm{mmol} / \mathrm{c}\left(\mathrm{C}_{2} \mathrm{O}_{4}\right)\right.$ $=300 \mu \mathrm{mol} / \mathrm{h}$. drate crystals. The system with the lowest oxalate concentration $(150 \mu \mathrm{mol} / \mathrm{l})$ (fig. 2) revealed a considerably slower increase in $\mathrm{N}_{\text {tot }}$ accompanied by a slight rise in $\mathrm{V}_{\text {tot, }}$ clearly showing the rate of crystal growth and total precipitate volume depends directly on the system oxalate concentration. Time-related changes in the $\mathrm{V}_{\text {single }}$ and $V_{\text {aggr }}$ volume fractions (fig. 3) show that individual

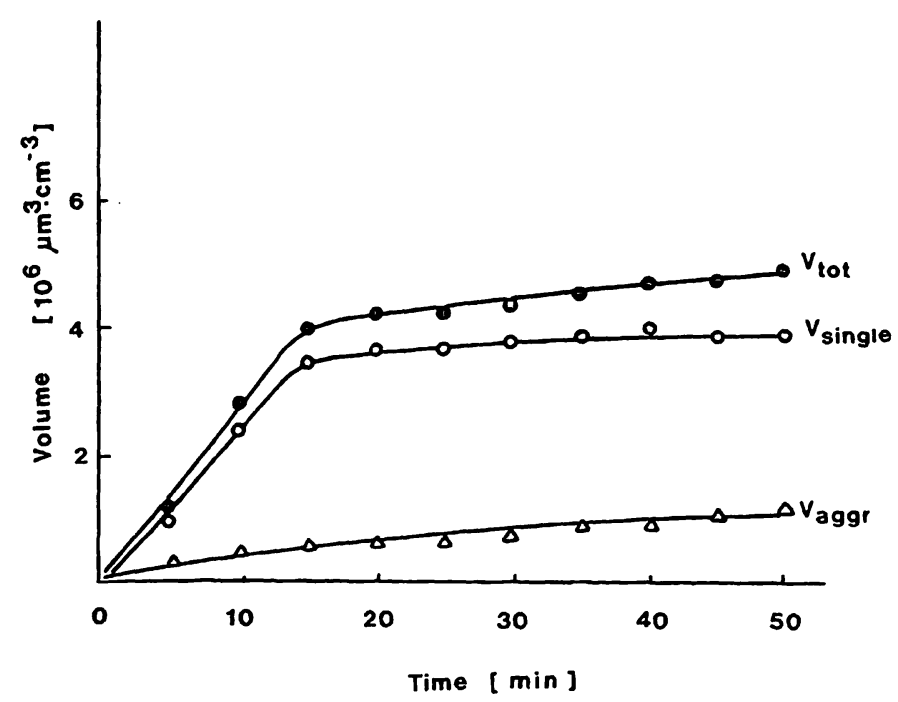

Fig. 3 Time-related change in total precipitate volume $\left(V_{\text {tot }}\right)$ and change in individual volume fractions $\left(\mathrm{V}_{\text {single }}\right.$ and $\left.\mathrm{V}_{\text {aggr }}\right)$ in a TammHorsfall protein-free system $\left(\mathrm{c}(\mathrm{NaCl})=150 \mathrm{mmol} / \mathrm{l}, \mathrm{c}\left(\mathrm{CaCl}_{2}\right.\right.$ $\left.=10 \mathrm{mmol} / \mathrm{l}, \mathrm{c}\left(\mathrm{C}_{2} \mathrm{O}_{4}\right)=300 \mu \mathrm{mol} / \mathrm{l}\right)$.

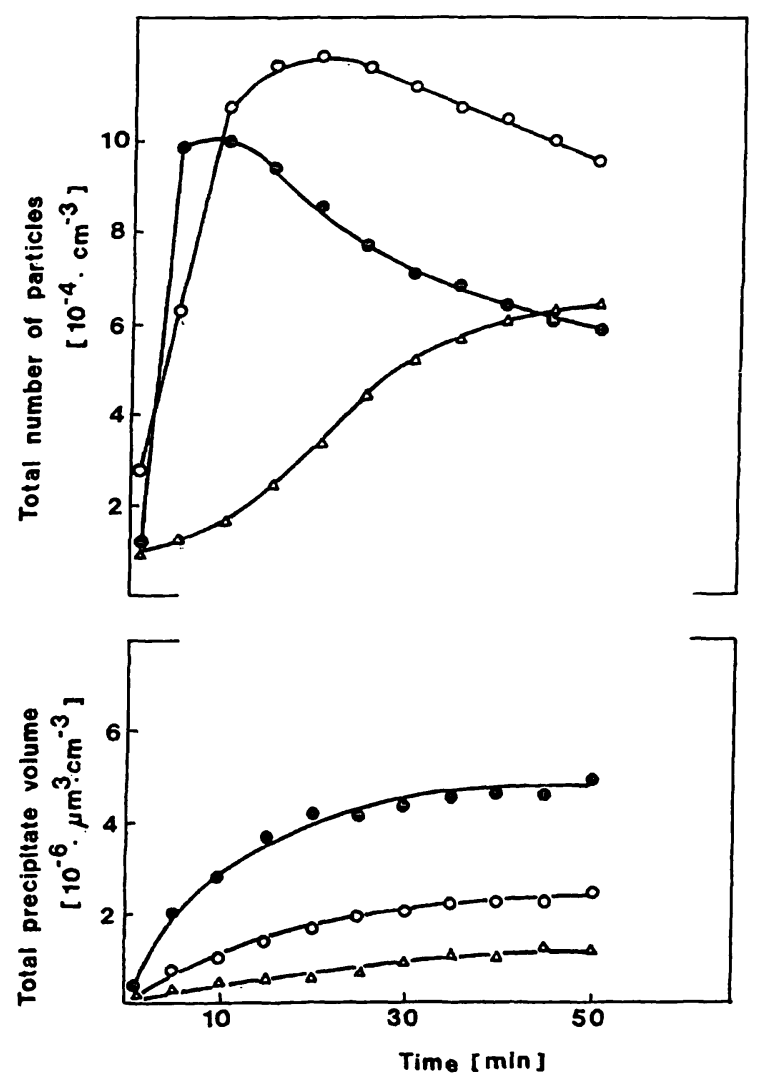

Fig. 2 Time-related change in total precipitate volume $\left(\mathrm{V}_{\text {tot }}\right)$ and in total number of particles $\left(\mathrm{N}_{\mathrm{to}}\right)$ in a Tamm-Horsfall protein-free system $\mathrm{c}\left(\mathrm{C}_{2} \mathrm{O}_{4}\right)=300 \mu \mathrm{mol} / \mathrm{l}(0), 200 \mu \mathrm{mol} / 1$ (O) and 150 $\mu \mathrm{mol} / /(\Delta)$. 
calcium oxalate monohydrate crystals $\left(\mathrm{V}_{\text {single }}\right)$ predominated throughout the period of precipitation, whereas the proportion of aggregates was low in comparison with the total precipitate volume.

\section{Calcium oxalate precipitation with Tamm-Horsfall protein}

During the precipitation, a large proportion in the total precipitate volume referred to Tamm-Horsfall protein molecules. Therefore, all results were corrected relative to Tamm-Horsfall protein as follows: the volume measured before the beginning of precipitation, i.e. before the addition of oxalate to the precipitating system, was substracted from the precipitate volume for each time of measurement.

A change in the particle distribution according to their number and volume in a system with concentration of Tamm-Horsfall protein of $10 \mathrm{mg} / 1$ is shown in figure 4 . The volume distribution histogram reveals a considerable proportion of particles with a volume diameter of $>8.2 \mu \mathrm{m}$ to have already been present at early precipitation times (15 min). With time, a shift toward greater crystal volumes was even more pronounced, pointing to the occurrence of calcium oxalate monohydrate crystal aggregation. This statement appears to be further supported by a presentation of time-related changes in the $\mathrm{V}_{\text {single }}$ and $\mathrm{V}_{\text {aggr }}$ volume fractions (fig. 5), with calcium oxalate monohydrate aggregates $\left(\mathrm{V}_{\text {aggr }}\right)$ making a large proportion of the total precipitate volume.

Figure 6 shows time-related changes in the $V_{\text {single }}$ and $\mathrm{V}_{\text {aggr }}$ volume fractions in the precipitating systems with lower Tamm-Horsfall protein concentrations (1, 2.5, 5 and $7.5 \mathrm{mg} / \mathrm{l}$ ). At Tamm-Horsfall protein concentrations greater than $2.5 \mathrm{mg} / \mathrm{l}$, a significant proportion of particles with a volume diameter $>8.2 \mu \mathrm{m}\left(\mathrm{V}_{\mathrm{aggr}}\right)$ was observed from the very beginning of precipitation. Optical microscopy of the precipitate showed them to be calcium oxalate monohydrate and Tamm-Horsfall protein aggregates. At the same time, a significant decrease in the volume of small particles with a volume diameter $\leq 8.2 \mu \mathrm{m}\left(\mathrm{V}_{\text {single }}\right)$ was observed. Also, the initial slopes

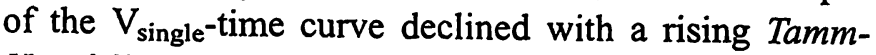
Horsfall protein concentration, whereas the volume of aggregated particles $\mathrm{V}_{\text {aggr }}$ (calcium oxalate monohydrate and Tamm-Horsfall protein aggregates, optical microscopy) increased with time and Tamm-Horsfall protein concentration (fig. 7).

\section{Discussion}

Literature reports on the role of Tamm-Horsfall protein in the formation of urinary calculi are quite contradic- tory. The question is still open whether Tamm-Horsfall protein acts as a promotor or as an inbibitor of calcium oxalate precipitation, and how it acts upon particular phases of the process of precipitation, i. e. nucleation, growth and aggregation. According to some authors, Tamm-Horsfall protein is an inhibitor of crystal growth $(7,8,12,17)$ and aggregation $(9,18)$, while others have shown promotion $(10,11,19)$ or no effect $(20,21)$. This contradiction is most probably due to the fact that various studies were performed under different experimental conditions (e.g., concentrations of electrolytes and Tamm-Horsfall protein in aqueous solution or ultrafiltered urine). Furthermore, Tamm-Horsfall protein is present in the urine in the form of subunits and aggregates, which may have different effects on crystal formation $(9,10)$. This disagreement in the reports relating to Tamm-Horsfall protein inspired us to embark upon a study of the effect of Tamm-Horsfall protein on the

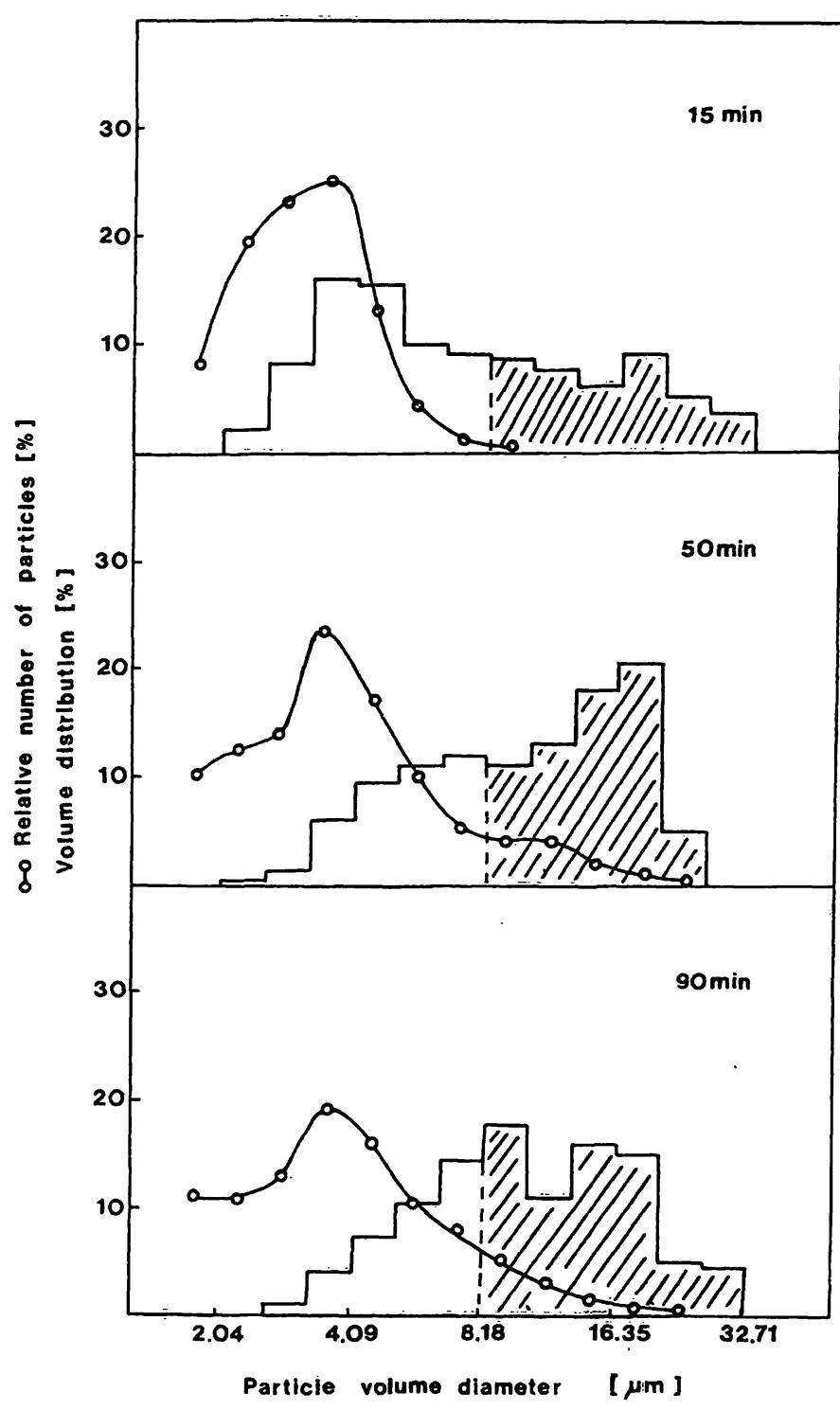

Fig. 4. Change in distribution according to number (-O-) and volume (histogram) of particles in a system with $10 \mathrm{mg} / \mathrm{Tamm}$ Horsfall protein $\left(\mathrm{c}(\mathrm{NaCl})=150 \mathrm{mmol} / \mathrm{l}, \mathrm{c}\left(\mathrm{CaCl}_{2}\right)=10 \mathrm{mmol} / \mathrm{h}\right.$, $\left.\mathrm{c}\left(\mathrm{C}_{2} \mathrm{O}_{4}\right)=300 \mu \mathrm{mol} / \mathrm{l}\right)$. 
growth and aggregation of calcium oxalate crystals as the most common constituent of urinary calculi. The study was carried out using conditions in which pure calcium oxalate monohydrate had been previously obtained (22), i. e. $\mathrm{c}(\mathrm{NaCl})=150 \mathrm{mmol} / \mathrm{l}, \mathrm{c}\left(\mathrm{CaCl}_{2}\right)=10$ $\mathrm{mmol} / \mathrm{l}, \mathrm{c}\left(\mathrm{C}_{2} \mathrm{O}_{4}\right)=300 \mu \mathrm{mol} / \mathrm{l}, \mathrm{pH} 6.0$ and temperature $310 \mathrm{~K}$. The concentration of Tamm-Horsfall protein varied between 1-10 mg/l. Solutions of Tamm-Horsfall

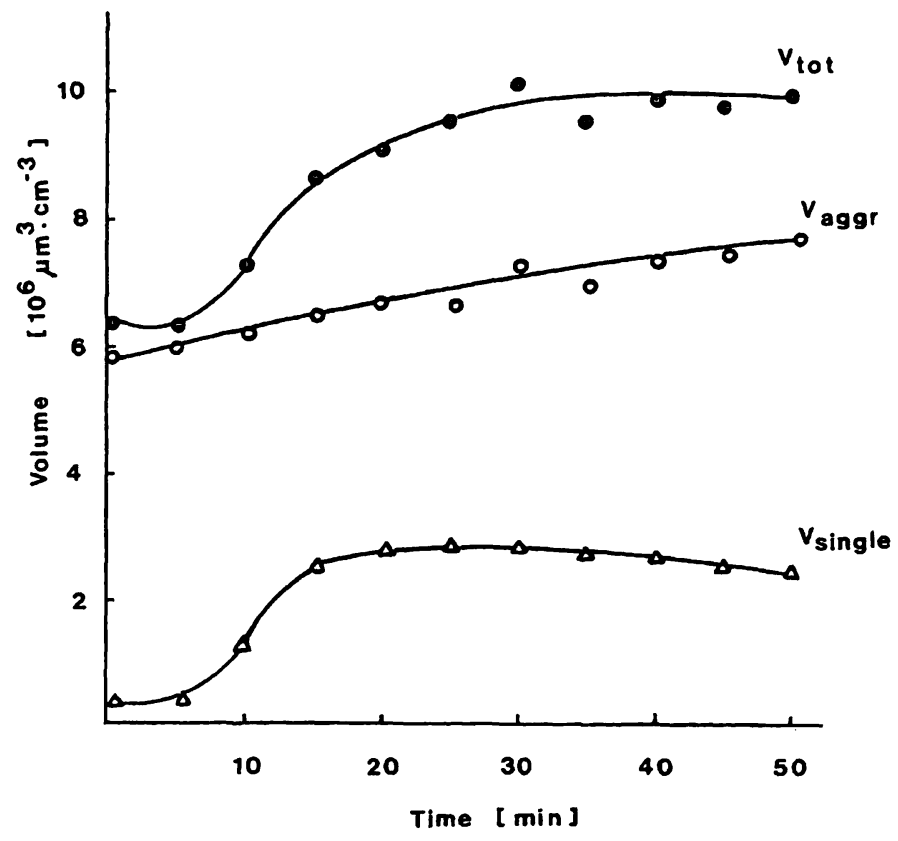

Fig. 5 Time-related change in total precipitate volume $\left(V_{t o t}\right)$ and change in individual volume fractions $\left(\mathrm{V}_{\text {single }}\right.$ and $\left.\mathrm{V}_{\text {aggr }}\right)$ in a system with $10 \mathrm{mg} / 1$ Hamm-Horsfall protein $(\mathrm{c}(\mathrm{NaCl})=150 \mathrm{mmol} / \mathrm{l}$, $\left.\mathrm{c}\left(\mathrm{CaCl}_{2}\right)=10 \mathrm{mmol} / \mathrm{l}, \mathrm{c}\left(\mathrm{C}_{2} \mathrm{O}_{4}\right)=300 \mu \mathrm{mol} / \mathrm{l}\right)$.
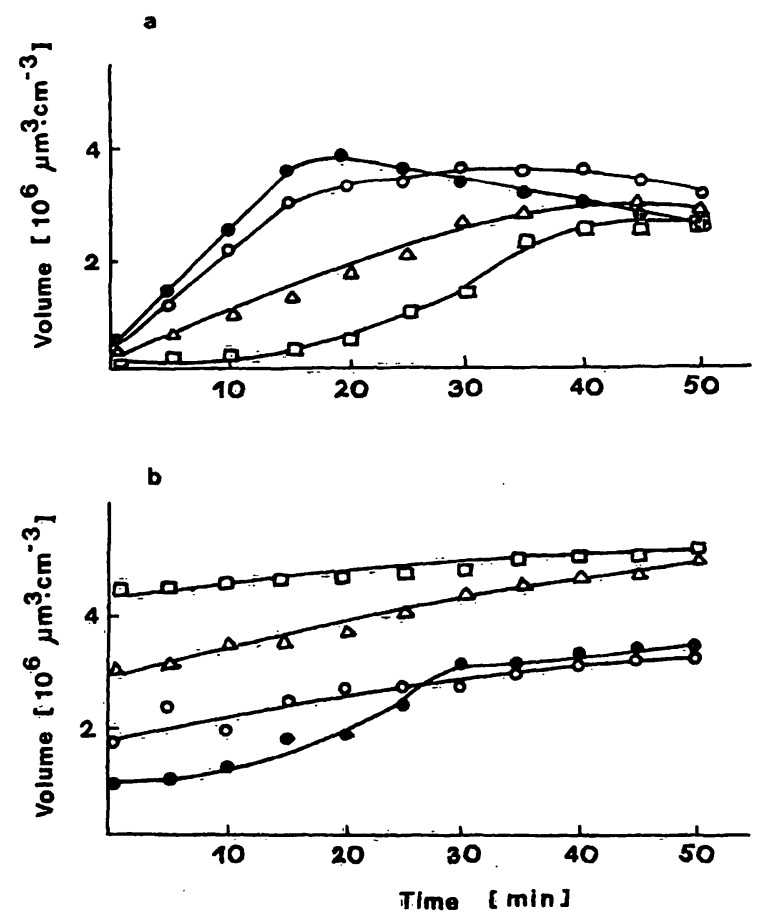

Fig. 6 Time-related change in $V_{\text {single }}(a)$ and $V_{\text {aggr }}$ (b) volume fractions in systems with $1 \mathrm{mg} / \mathrm{l}(\bullet), 2.6 \mathrm{mg} / \mathrm{l}(0), 5 \mathrm{mg} / \mathrm{l}(\Delta)$ and $7.5 \mathrm{mg} / \mathrm{l}$ () Tamm-Horsfall protein. protein concentrations higher than $10 \mathrm{mg} / 1$ were avoided because of additional self-aggregation of Tamm-Horsfall protein, suspensions of which were not suitable for Coulter Counter measurements. Comparison of the histograms of the particle volume distribution in a system with $10 \mathrm{mg} / 1$ of Tamm-Horsfall protein (fig. 4) and in a control system without Tamm-Horsfall protein (fig. 1) reveals the particles of a volume diameter of $\leq 8.2 \mu \mathrm{m}$ (individual calcium oxalate monohydrate crystals) predominated in the control system throughout the period of precipitation, whereas in the system with TammHorsfall protein large particles of $\mathrm{d}>16.4 \mu \mathrm{m}$ predominated, suggesting the occurrence of calcium oxalate monohydrate crystal aggregation in the presence of Tamm-Horsfall protein. A diagram illustrating the timerelated change in the $V_{\text {single }}$ and $V_{\text {aggr }}$ volume fractions (fig. 5) also differs considerably from that for the control system (fig. 3). In the control system, the course of the

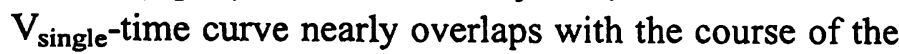
$\mathrm{V}_{\text {tot }}$-time curve. The proportion of the aggregates $\mathrm{V}_{\mathrm{aggr}}$ relative to the total precipitate volume was small, and the volume of aggregated particles in min 50 of precipitation was $1.1 \times 10^{6} \mu^{3} \mathrm{~cm}^{-3}$. In contrast, in the system with $10 \mathrm{mg} / \mathrm{l}$ of Tamm-Horsfall protein, $\mathrm{V}_{\mathrm{aggr}}$ accounted for a large proportion in the total precipitate volume, whereas the volume of aggregated particles in min 50 of precipitation was $7.6 \times 10^{6} \mu^{3} \mathrm{~cm}^{-3}$, which confirms the hypothesis that Tamm-Horsfall protein stimulates the aggregation of calcium oxalate monohydrate and is consistent with the results obtained by other authors (10) who consider the polymer molecule of Tamm-Horsfall protein to act as a promoter of calcium oxalate crystal aggregation. Other authors, however, advocate the opposite opinion, probably resulting from

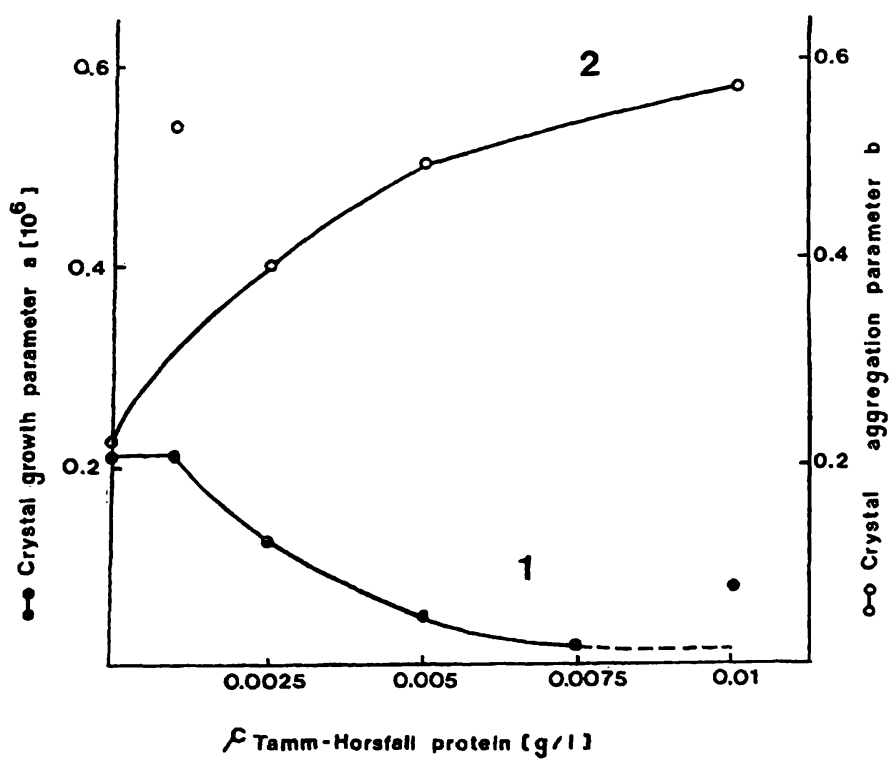

Fig. 7 Dependence of the parameters of growth (a, curve 1) and aggregation (b, curve 2) of calcium oxalate monohydrate crystal on Tamm-Horsfall protein concentration. 
studies with Tamm-Horsfall protein subunits (9) or with very low Tamm-Horsfall protein concentrations (11).

The time-related changes in the $\mathrm{V}_{\text {single }}$ and $\mathrm{V}_{\text {aggr }}$ volume fractions (fig. 6) show that in the systems with 1-7.5 $\mathrm{mg} / \mathrm{l}$ of Tamm-Horsfall protein, a gradual increase in the concentration of Tamm-Horsfall protein resulted in a significant decrease in the small particle volume $\left(\mathrm{V}_{\text {single }}\right)$ early during the procedure of precipitation (by $\min 20$ ), indicating inhibition of crystal growth. The volume of aggregated particles increased simultaneously, confirming the above conclusion that Tamm-Horsfall protein acts as a promotor of the calcium oxalate monohydrate crystal aggregation. A change in the calcium oxalate monohydrate crystal growth (a) and aggregation (b) parameters, depending on the concentration of TammHorsfall protein in the precipitating system (fig. 7), clearly shows that in the given experimental conditions, the presence of Tamm-Horsfall protein led to crystal growth inhibition (curve 1), which was most pronounced at a Tamm-Horsfall protein concentration of $10 \mathrm{mg} / \mathrm{l}$. At the same time, the parameter describing the intensity of aggregation rose with the increase in the system concentration of Tamm-Horsfall protein (cutve 2). Optical microscopy revealed that the aggregates consist of calcium oxalate monohydrate and Tamm-Horsfall protein, and that crystal growth is slowed down just by the process of calcium oxalate monohydrate crystal aggregation to Tamm-Horsfall protein molecules, supporting the conclusion that, in the given experimental conditions, TammHorsfall protein acts as an inhibitor of calcium oxalate monohydrate crystal growth and as a promotor of their aggregation. The results obtained in this study may contribute to better understanding of the role of Tamm-Horsfall protein in the formation of a solid phase in the urine, which may be important in relation to urolithiasis.

\section{References}

1. McKenzie JK, McQueen EG. Immunofluorescence localization of Tamm-Horsfall mucoprotein in human kidney. J Clin Pathol 1969; 22:334-9.

2. Pollak VE, Arbel RD. The distribution of Tamm-Horsfall mucoprotein (uromucoid) in the human nephron. Nephron 1969; 61:667-72.

3. Schenk EA, Schwartz RH, Lewis RA. Tamm-Horsfall mucoprotein. I. Localization in the kidney. Lab Invest 1971; 25:92-5.

4. Hoyer JR, Resnick JS, Michael AF, Vernier RL. Ontogeny of Tamm-Horsfall urinary glycoprotein. Lab Invest 1974; 30:757-61.

5. Kumar S, Muchomore A. Tamm-Horsfall protein-uromodulin (1950-1990). Kidney Int 1990; 1395-401.

6. Maxfield M. Molecular forms of human urinary mucoprotein present under physiological conditions. Biochim Biophys Acta 1961; 49:548-58.

7. Fellstrom B, Danielson BG, Ljunghall S, Wikstrom B. Crystal inhibition: the effects of polyanions on calcium oxalate crystal growth. Clin Chim Acta 1986; 158:229-35.

8. Kitamura T, Pak CYC. Tamm and Horsfall glycoprotein does not promote spontaneous precipitation and crystal growth of calcium oxalate in vitro. J Urol 1982; 127:1024-5.

9. Hess B, Nakagawa Y, Coe FL. Inhibition of calcium oxalate monohydrate crystal aggregation by urine proteins. Am J Physiol 1989; 26:F99-F106.

10. Scurr DS, Robertson WG. Modifiers of calcium oxalate crystallization found in urine. II. Studies in their mode of action in an artificial urine. J Urol 1986; 136:128-31.

11. Scurr DS, Robertson WG. Modifiers of calcium oxalate crystallization found in urine. III. Studies on the role of TammHorsfall mucoprotein and of ionic strength. J Urol 1986; 136:505-7.

12. Lopez M, Nakagawa Y, Coe FL, Tsai C, Michael AF, Scheinmann JI. Immunochemistry of urinary calcium oxalate crystal growth inhibitor (CGI). Kidney Int 1986; 29:829-33.

13. Tamm I, Horsfall FL Jr. Characterization and separation of inhibitor of viral hemagglutination present in urine. Proc Soc Exp Biol Med 1950; 74:108-14.

14. Tamm I, Horsfall FL Jr. A mucoprotein derived from human urine which reacts with influenza, mumps and Newcastle diseases viruses. J Exp Med 1952; 95:71-97.

15. Rieder HP. Eine neue Modifikation der $\mathrm{Cu}$-Folin-Methode zur Bestimmung des Totalproteins im Liquor cerebrospinalis. Klin Wochenschr 1966; 44:1036-8.

16. Hamlin LM, Fisch WW. Physical properties of Tamm-Horsfall glycoprotein and its glycopolypeptide. Int J Peptide Protein Res 1977; 10:270-6.

17. Gjalback JC, Robertson WG. Does urine from stone formers contain macromolecules which promote the crystal growth rate of calcium oxalate crystal in vitro. Clin Chim Acta 1980; 108:75-80.

18. Ryall RL, Harnett RM, Hibberd CM, Edyvane KA, Marshall VR. Effects of chondroitin sulphate, human serum albumin and Tamm-Horsfall mucoprotein on calcium oxalate crystallization in undiluted human urine. Urol Res 1991; 19:181-8.

19. Rose GA, Sulaiman S. Tamm-Horsfall mucoproteins promote calcium oxalate crystal formation in urine: quantiative studies. J Urol 1982; 127:177-9.

20. Sophasan S, Chatasingh S, Thanaphaichitr $P$, Dhanamitta $S$. Tamm-Horsfall mucoprotein in urine of potential bladder stone formers. J Urol 1980; 124:522-4.

21. Worecester E, Nakagawa Y, Wabner CL, Kumar S, Coe FL Jr. Crystal adsorption and growth slowing by nephrocalcin, albumin, and Tamm-Horsfall protein. Am J Physiol 1988; 255:F1197-205.

22. Babić-Invančić V, Fueredi-Milhofer $H$, Purgarić $P$, Bmičevi N, Despotovi Z. Precipitation of calcium oxalates from high ionic strength solution. III. The influence of reactant concentration on the properties of the precipitates. J Cryst Growth 1985; $71: 655-63$.

Jasminka Benković, M.S.

Clinical Institute of Laboratory Diagnosis

Zagreb University Hospital

Kišpatićeva 12

10000 Zagreb, Croatia 